\title{
TAXONOMY AND NOMENCLATURE OF RUBUS ULMIFOLIUS AND RUBUS SANCTUS (ROSACEAE)
}

\author{
E. MONASTERIO-HUELIN* \& H. E. WEBER†
}

The taxonomy and nomenclature of the most common, closely related brambles of the Mediterranean area are treated. These include $R$. ulmifolius Schott ( $R$. discolor, $R$. rusticanus, $R$. inermis) and Rubus sanctus $\mathrm{Schreber}(R$. sanguineus, $R$. dalmatinus, $R$. anatolicus) (Rosaceae). The species are illustrated, the types are given, and variability, synonymy and distribution is indicated. Fifteen names are lectotypified.

Keywords. Brambles, lectotypifications, Mediterranean flora.

\section{INTRODUCTION}

The European Rubus flora consists mainly of polyploid, mostly tetraploid, facultative apomicts. By occasional hybridization and segregation new morphotypes may arise, which when stabilized primarily by subsequent apomixis may spread over large areas. There are 'local species' limited to a restricted area, and others with a regional or much wider distribution.

Only six bramble species in Europe seem to be diploid and sexual. Two of them, the well-known Mediterranean Rubus ulmifolius Schott ( $R$. rusticanus Mercier) and the more eastern $R$. sanctus Schreb. ( $R$. anatolicus [Focke] Hausskn.), are the subject of this paper. Both species show a high degree of morphological variability, probably due partly to recombinations within cross-fertilized populations.

The great variability within the $R$. ulmifolius- $R$. sanctus complex, with often very similar hybridogenous biotypes, has resulted in the publication of many valueless taxa. Some examples are those published by Ripart \& Genevier in Genevier (1868) and by Sudre (1908-1913), who arranged 20 subspecies, 'microgenera' and 42 varieties within $R$. ulmifolius Schott. Other botanists such as Sennen $(1928,1936)$ paid special attention to numerous hybrids.

This study is based on investigation in the field and of herbarium material at B, BC, BM, BP, C, CAT, CGE, COI, FI, G, GZU, JE, KIEL, M, MA, MAF, MUB, PAL, PRC, W, WU and We (=hb. H.E. Weber). To save space, lists of representative specimens are not included here. Details are given in Weber (1986) and MonasterioHuelin (1993).

Besides those names treated in this paper, many others have been applied to the R. ulmifolius complex by several authors (e.g. Malbranche, 1879; Boulay, 1898; Legrain, 1958). They have not been used frequently, and the type material has not been found. Their identification cannot be assured based upon the protologue alone. These names thus remain doubtful.

* Real Jardín Botánico, Plaza de Murillo 2, Madrid, Spain.

+ University of Vechta. Driverstraße 22. D-49377 Vechta, Germany. 


\section{RUBUS ULMIFOLIUS}

Rubus ulmifolius Schott, Isis (Oken) 2: 821 (1818), non R. ulmifolius J. Presl \& C. Presl, Delic. Prag. : 223 (1822). Fig. 1.

Syn.: $R$. discolor [subsp.] ulmifolius (Schott) Nyman, Consp. F1. Eur. 1: 217 (1878), comb. superfl. $R$. fruticosus var. ulmifolius (Schott) Fiori in Fiori \& Paol., Fl. Italia 1(2): 579 (1898). Type: 'In sepibus maritimis Hispania, Schott' (W, lectotype: H.E. Weber, 1986: 216).

Stem high-arching, angled with furrowed sides, pruinose, purple, 6-10 $\mathrm{mm}$ diameter, with simple and tufted hairs (10-100 per $1 \mathrm{~cm}$ of one of the five sides) and scattered to numerous stellate hairs; prickles $5-11$ per $5 \mathrm{~cm}$, subequal, $7-10 \mathrm{~mm}$, patent and straight to strongly curved from a broad $(5-9 \mathrm{~mm})$ and usually pubescent base. Leaves pedate, sometimes digitate; leaflets (3-)5, leathery, dark green, glabrous or with up to 40 hairs per $\mathrm{cm}^{2}$ above, white-felted and without longer simple hairs beneath (hairs not felt by touch); terminal leaflet obovate, elliptical or (particularly around the Mediterranean shore) truncate with a cuspidate, acuminate or submucronate apex (8-) 10-15mm and rounded to (slightly) cordate base, irregularly serrate with prominent principal teeth $(1.5-4(-5) \mathrm{mm}$ deep); petiole as long as or longer than the basal leaflets, glabrous or with numerous stellate hairs, with $6-10$ curved prickles 3-4mm. Inflorescence usually wide, cylindrical or conical; with 3-5-foliolate leaves below and lanceolate simple leaves above, not leafy $12-17(-20) \mathrm{cm}$ below the apex. Rachis mostly pruinose, furrowed, grey to white-felted, sometimes with sparse simple hairs, and with sparse to numerous $(3-14$ per $5 \mathrm{~cm})$, broad-based $(3-5(-8) \mathrm{mm})$, patent to curved prickles $5-8 \mathrm{~mm}$; pedicels $6-15(-20) \mathrm{mm}$, grey to white-felted, usually without longer simple hairs and with 2-9, declining or curved prickles, 1-3mm. Sepals reflexed, white-felted. Petals roundish or elliptical, 9-14x $7-12 \mathrm{~mm}$, somewhat purplish or deep to pale pink, rarely white. Anthers glabrous or with (mostly few) hairs. Carpels hairy. Receptacle hairy. $2 \mathrm{n}=14$.

Distribution. Great Britain (very rare in Scotland), Ireland, The Netherlands, Germany (parts of Rhineland), Luxembourg, Belgium, France, Switzerland, Liechtenstein, Slovenia, Croatia, Herzegovina, Italy (except Apulia), Spain, Portugal, Morocco, northern Tunisia and Algeria, Canary Islands, Azores (cf. map in Weber, 1995: 369). Introduced to other parts of Central Europe, Denmark, south Sweden; Greece, Israel and some other eastern Mediterranean regions; North and South America, South Africa, Australia, and New Zealand.

Variability. We consider $R$. ulmifolius to be represented by four varieties:

\section{(1) var. ulmifolius}

Syn.: $R$. discolor Weihe \& Nees, Rubi German.: 46, t. 20 (1825). R. vulgaris [f.] discolor (Weihe \& Nees) Bluff \& Fingerh., Comp. Fl. German. Ed. 2. 1(2): 194 (1837). R. fruticosus var. discolor (Weihe \& Nees) G. Mey., Fl. Hanov. Excurs.: 168 (1849). R. vulgaris [var.] discolor (Weihe \& Nees) Wirtg., Fl. Coblenz: 54 (1841). 




FIG. 1. Rubus ulmifolius Schott. Lectotype (W). 
R. pubescens [var.] discolor (Weihe \& Nees) Karsch, Phan.-Fl. Westfalen: 162 (1853). R. pilosus [var.] discolor (Weihe \& Nees) Dumort., Bull. Soc. Roy. Bot. Belgique 2: 229 (1863). R. fruticosus subsp. discolor (Weihe \& Nees) Syme in J.E. Smith \& C.E. Sowerby, Engl. Bot. 3. Ed. 3: 171 (1864). R. villicaulis subsp. discolor (Weihe \& Nees) Celak., Prodr. Fl. Böhmen 3: 639 (1875). Type: 'Am Rhein, sine dat., Weihe' (JE, lectotype: Beek, 1979: 208, 'LE').

R. siculus C. Presl., F1. Sicul. 1: xxiv (1826). Type: 'Sicilia, Val di Noto V-1917. Presl (PRC 909, lectotype selected here).

R. hispanicus Willk., Bot. Zeitung (Berlin) 2: 819 (1844). R. amoenus var. hispanicus (Willk.) Willk., Grundz. Pfl.-Verbr. Iber. Halbins.: 168 (1896). Type: 'Prope urbem Granada, 0-5000', 19-VII-1844, Willk. $n^{\prime 2} 157$ ', sub 'R. tomentosus W. $\beta$ amoenus Port'. (COI, lectotype: Monasterio-Huelin, 1993: 63).

R. panormitanus Tineo, Pl. Rar. Sicil. 24 (1846). R. fruticosus var. panormitanus (Tineo) Fiori in Fiori \& Paol., Fl. Italia 1(2): 579 (1898). Type: 'Maggio, Piano di Gregoli, Sotto la Scala di Massedu' (PAL, lectotype selected here).

R. rusticanus Mercier in Reut., Cat. Pl. Vasc. Genève ed. 2: 279 (1861). R. discolor subsp. rusticanus (Mercier) Nyman, Consp. Fl. Eur. Suppl. 2: 106 (1889). R. ulmifolius $[\alpha]$ rusticanus (Mercier) Samp., Rubus Port.: 47 (1904). R. ulmifolius subsp. rusticanus (Mercier) Focke in Asch. \& Graebn., Syn. Mitteleur. Fl. 6: 501 (1902). R. ulmifolius var. rusticanus (Mercier) Merino, Fl. Galicia 1: 446 (1905). Type: 'Francia, Sour Tannay [...], 1858, Mercier' (G, lectotype: Weber \& MonasterioHuelin in Monasterio-Huelin, 1993: 63).

$R$. amoenus var. microphyllus Lange, Vidensk. Meddel. Dansk Naturhist. Foren. Kjøbenhavn 17: 146 (1866), nom. inval. (Art. 43.1 ICBN). Specimen originale: 'ad sepes pr. oppid. Santander, 16-X-1852, Lange' (C).

R. albescens Boulay \& Gillot, Assoc. Rubol. Exs. n 216 (1877). Type: 'Saône-etLoire, Branges, Gillot. Boulay, Assoc. Rubol. Exs. n 216' (CGE, lectotype selected here).

R. legionensis Gand., Mém. Soc. Emul. Doubs. Ser. 5, 8: 121 (1884). R. minutiflorus Lange, Descr. Icon. Pl. Nov. 2, t. 3 (1864), nom. illeg., non $R$. minutiflorus P.J. Müll.. Jahresber. Pollichia 16-17: 235 (1859). R. ulmifolius [var. teratologicae] minutiflorus (Lange) Focke, Sp. Rub. 3: 155 (1914). Type: '[León], Carucedo, (El Bierzo), 19-VII-1852, Lange' (C, lectotype: Monasterio-Huelin, 1993: 63).

R. crispulus Gand., Mém. Soc. Emul. Doubs. Ser. 5, 8: 157 (1884). Type: 'Arnas, Adreias, 27-VII-1878, Gandoger. Gandoger Fl. Gallica Exs. n'248' (CGE, lectotype selected here).

R. oculus-junonis Gand., Mém. Soc. Emul. Doubs. Ser. 5, 8: 173 (1884). Type: 'Arnas in dumetis, 10-VII-1877, Gandoger. Gandoger Fl. Gallica Exs. n' 61' (W. lectotype selected here).

R. aetneus Tornab., F1. Sicul.: 229, tab. 1, fig. A (1887). Type: 'Aetnae, Viagrante' (CAT, lectotype selected here).

R. valentinus Pau, Not. Bot. Fl. Españ. 1: 11 (1887). Type: 'Valentia [Castellón]: Segorbe loco dicto Marroyo, 29-VI-1886, Pau 961' (MA 54302. lectotype: Monasterio-Huelin \& Weber in Monasterio-Huelin, 1993: 64). 
R. segobricensis Pau. Not. Bot. Fl. Españ. 3: 29 (1889), nom. nud. Specimen originale: 'Almagrán, Segorbe, 28-VI-1889, Pau' (MA 54303, MA 54304).

R. appenninus Evers, Deutsche Bot. Monastsschr. 14: 63 (1896) [in Deutsche Bot. Monastsschr. 13: 149 (1895), nom. nud.]. R. tomentellus f. appenninus (Evers) Hruby, Repert. Spec. Nov. Regni Veg. 33: 903 (1934). Type: 'Italia: Abruzzi, Solmona in pietrosis propi La Forca ad pagum Cocullo, 1-VII-1889, Evers 8353' (GZU, lectotype selected here).

R. cocullotinus Evers, Deutsche Bot. Monastsschr. 14: 24 (1896) [Deutsche Bot. Monatsschr. 13: 148 (1895), nom. nud.]. Type: 'Italia: Abruzzi, Solmona, pietrosis declivibus ad Cocullo, 1-VII-1889, Evers 8355' (GZU, lectotype selected here).

R. ulmifolius ['variationen'] bruginoensis Evers, Verh. Zool.-Bot. Ges. Wien 46: 63 (1896). Type: 'Italia, Tirola australis: Mori, in dunetis rupestribus montis Brugino, super Nomesino, 15-V-1894, Evers 8789' (GZU, lectotype selected here; W, isolectotype).

R. ulmifolius ['variationen'] tridentinus Evers, Verh. Zool.-Bot. Ges. Wien 46: 63 (1896). Type: 'Tridentum, Muralta, in vinetis, ad vias in muris, in pietrosis, 30-IX-1889/15-VI-1891, Evers 8594' (W, lectotype selected here).

R. ulmifolius f. rrichantherus Sabr., Repert. Spec. Nov. Regni Veg. 13: 7 (1913). Type: 'M. Gargano, Mamfredoniana, Sardegna, 18-V-1887, Sabransky' (WU, lectotype selected here).

R. longipetiolatus Sennen, P1. Espagne n 5289 (1925), nom. illeg., non R. longipetiolatus Hülsen, Verh. Bot. Vereins Prov. Brandenburg 40: 31 (1898). Type: 'Cerdagne: Llivia, val de l'Estahuja, 1350 m, 9-IX-1925, Sennen' (BC 804166, lectotype: Monasterio-Huelin, 1993: 63).

R. simusifolius Sennen, Pl. Espagne n 6067 (1927). Type: 'Cerdagne: Llivia, haies en sites découverts, 1200 m, 23-V-1927, Sennen' (MA 54364, lectotype: MonasterioHuelin, 1993: 64).

R. edouardi Sennen, P1. Espagne n 6066 (1927), nom. nud. Specimen originale: 'Cerdagne: Sarèje, lieux découverts, margens, sur le granit, $1350 \mathrm{~m}$, Sennen' (MA 54365. MA 470228).

R. bujedanus Sennen \& Elias ex Sennen, Bol. Soc. Ibér. Ci. Nat. 26: 184 (1928). Type: 'Castille: Tertres à Bugedo, VIII-1911, Hno. Elías, Sennen n 1289', sub 'R. tomentosa + ulmifolius' (MA 54201, lectotype: Monasterio-Huelin, 1993: 64).

$R$ castellanus Sennen \& Elías ex Sennen, Bol. Soc. Ibér. Ci. Nat. 26: 183 (1928). Type: 'Logroño [Burgos]: Sierra Obarenes à Cellorigo, 16-VI-1922, Hno. Elias, Sennen n`4553' (MA 54152, lectotype: Monasterio-Huelin, 1993: 64).

R. gerundensis Sennen, Diagn, Nouv. Pl. Espagne Maroc: 43 (1936). Type: -Gérone: S. Feliu de Pallarols à la Salut, 1020m, 8-VIII-1928, Hnos. Gonzalo et Teodoro, Sennen n 6851' (MA 424643, lectotype: Monasterio-Huelin, 1993: 64).

The typical form is as described above. The leaves are usually smaller in dry, hot localities (such plants were called $R$. panormitanus Tineo and $R$. amoenus var. microphyllus Lange). This and some other variability is due merely to environmental influences and does not merit taxonomic recognition. 


\section{(2) var. anoplothyrsus Sudre}

Rubi Eur.: 70 (1909), as R. ulmifolius subsp. subtruncatus var. anoplothyrsus. Type: 'France. Ariège: Usson-les-Bains, chemin du château, $800 \mathrm{~m}$, terrain granitique, 10-VIII-1909, Sudre, Batoth. Eur. n 311' (MA 54298, lectotype: Monasterio-Huelin, 1993: 63).

Syn.: R. flagellaris var. inermis Ser. in DC., Prodr. 2: 559 (1825). Type: 'Rubus inermis Gou., inermis W.' (G, lectotype selected here).

R. cyrenaicae Hruby, Pamp. in Arch. Bot. (Forli) 12: 28 (1936). Type: 'LibiaCirenaica: U. Derna, 12 Mag. 1934, R. Pampanini \& R. Pichi-Sermolli', sub ' $R$. cyrenicus Hruby 232' (FI 3413, lectotype selected here).

R. inermis Pourr., Hist. \& Mém. Acad. Roy. Sci. Toulouse 3: 326 ( 1788 ). R. vulgaris Bubani, Fl. Pyren. 2: 605 (1900), nom. illeg. Type: 'Pourret 3168' (MAFPOURR, lectotype: Beek, 1979: 206).

$R$. inermis Willd., Enum. Plant. Horti Berol.: 548 (1809), nom. illeg., non R. inermis Pourr. R. ulmifolius var. ['lusus et varietates teratologicae'] inermis (Ser. in DC.) Focke (cit. Willd.), Sp. Rub. 3: 154 (1914). Type: 'R. inermis' (B-W 9891, holotype).

Prickles lacking altogether or very sparse. Known mainly from botanical gardens.

Taxonomical and nomenclatural remarks. The oldest name for this taxon at the rank of variety is $R$. flagellaris var. inermis Ser., but this epithet cannot be combined here with $R$. ulmifolius Schott (Art. 11.4 ICBN). Such a combination would be illegitimate under Art. 53.5 ICBN, due to the previous existence of the combination $R$. ulmifolius var. inermis Focke, which was made in 1914, and is based on another type.

The epithet inermis Willd. is illegitimate at specific rank because it is a later homonym. It was first transferred in 1825 to the rank of variety by Seringe. Here the epithet is legitimized (Art. 58.3 ICBN) and should be cited without the previous author Willdenow. The new name can be based on a type other than the illegitimate 'basionym'; here we have selected for this purpose a specimen in the collection of De Candolle.

The name Rubus inermis Pourr. is based on a panicle of poor quality, which may or may not belong to $R$. ulmifolius. It might belong to one of the many singular biotypes, mostly hybrids of $R$. ulmifolius, which are to be found on the Iberian Peninsula. Since $R$. inermis has priority over $R$. ulmifolius, Beek (1979) has replaced the latter name with the former. Because of the doubtful type specimen, however, Weber (1986), Edees \& Newton (1988) and the present authors, as well as nearly all other taxonomists, rejected the name $R$. inermis Pourr. and kept the name R. ulmifolius Schott, which has been widely and persistently used for this taxon and is typified by an unambiguous type specimen.

The name Rubus inermis Willd. also remains doubtful, due to the poor holotype which consists only of the tip of a primocane (barren stem) with some small leaves. Certainly the specimen represents a member of the $R$. ulmifolius complex including $R$. sanctus. Because the leaves are covered with stellate hairs above, but have only stellate hairs (not felt by touch) beneath, the specimen is ambiguous. 
(3) var. bellidiflorus (K. Koch) Focke

Sp. Rub. 3: 378 (1914), sub 'lusus et varietates teratologicae', quoad descript. R. bellidiflorus K. Koch, Dendrologie 1: 292 (1869).

With double flowers. Grown in gardens for ornamental purposes.

(4) var. chlorocarpus (Boreau ex Genev.) Focke

Sp. Rub. 3: 378 (1914), sub 'lusus et varietates teratologicae' et sphalmate 'clorococcus', quoad descript. $R$. chlorocarpus Boreau ex Genev. in Mém. Soc. Acad. Maine Loire 24: 239 (1869) [Essai Monogr. Rubus]. Type: Maine-et Loire: Villemoisan, leg. Boreau (holotype, n.v.).

Mature fruits yellowish-green. A very rare mutant lacking anthocyanin in the fruits (as occasionally in some other plants, e.g. Rubus idaeus L., Ribes rubrum L., Sambucus nigra L.).

\section{$R U B U S$ SANCTUS}

Rubus sanctus Schreber, Ic. Descr. Pl.: 15 (1756). R. ulmifolius subsp. sanctus (Schreb.) Sudre, Rubi Eur.: 76 (1909). R. albicans Krasan, Verh. K. K. Zool.-Bot. Ges. Wien 115: 357, nom. superfl. $R$. rotundifolius Krasan, ibid., nom. superfl. Type: 'Crete, Schreber 43' (M, holotype). Fig. 2.

Syn.: R. fruticosus [subsp.] dalmatinus Tratt., Rosac. Monogr. 3: 33 (1823). $R$. fruticosus var. dalmatinus Ser. in DC., Prodr. 2: 561 (1825). R. dalmatinus (Tratt.) Guss., Fl. Sicul. Syn. 1: 567 (1843), 'R. dalmaticus', R. ulmifolius subsp. dalmatinus (Tratt.) Focke, Syn. Rub. Germ.: 184 (1877). R. ulmifolius var. dalmaticus (Tratt.) Evers, Verh. Zool.-Bot. Ges. Wien 46: 62 (1896). R. fruticosus f. dalmantinus (Tratt.) Fiori in Fiori \& Paol.. Fl. Italia 1(2): 579 (1898). Type: In Dalmatia ad sepes, Portenschlag (n.v.).

R. sanguineus Friv., Flora 18: 334 (1835). Type: 'Macedonia, Frivaldsz.' ( KIEL, lectotype selected here).

R. fruticosus var. amoenus Port. ex Vis., F1. Dalmat. 3: 248 (1851). R. amoenus (Port. ex Vis.) Focke, Abh. Naturwiss. Vereine Bremen 1: 286 (1868), comb. illeg., non $R$. amoenus Köhler in Wimm. \& Grab., Fl. Siles. 1(2): 54 (1829). R. discolor subsp. amoenus (Port. ex Vis.) Nyman, Consp. Fl. Eur. Suppl. 2: 106 (1891). R. discolor var. amoenus (Port.) Pérez Lara, Anales Soc. Esp. Hist. Nat. 20: 92 (1891). Type: Unknown (W?, examined and described by A. Kerner, 1872, see below).

R. ulmifolius subsp. anatolicus Focke, Abh. Naturwiss. Vereine Bremen 9: 335 (1886). R. anatolicus (Focke) Hausskn., Mitth. Thüring. Bot. Vereins 5: 90 (1893). R. ulmifolius var. anatolicus Heldr., Bull. Herb. Boissier 6: 297 (1898). Type: 'Grecia: Attica, Phalari, 1. d. Moschato, 5-VIII-1884, hb. Heldreich' (W, lectotype selected here: BP, isolectotype). 


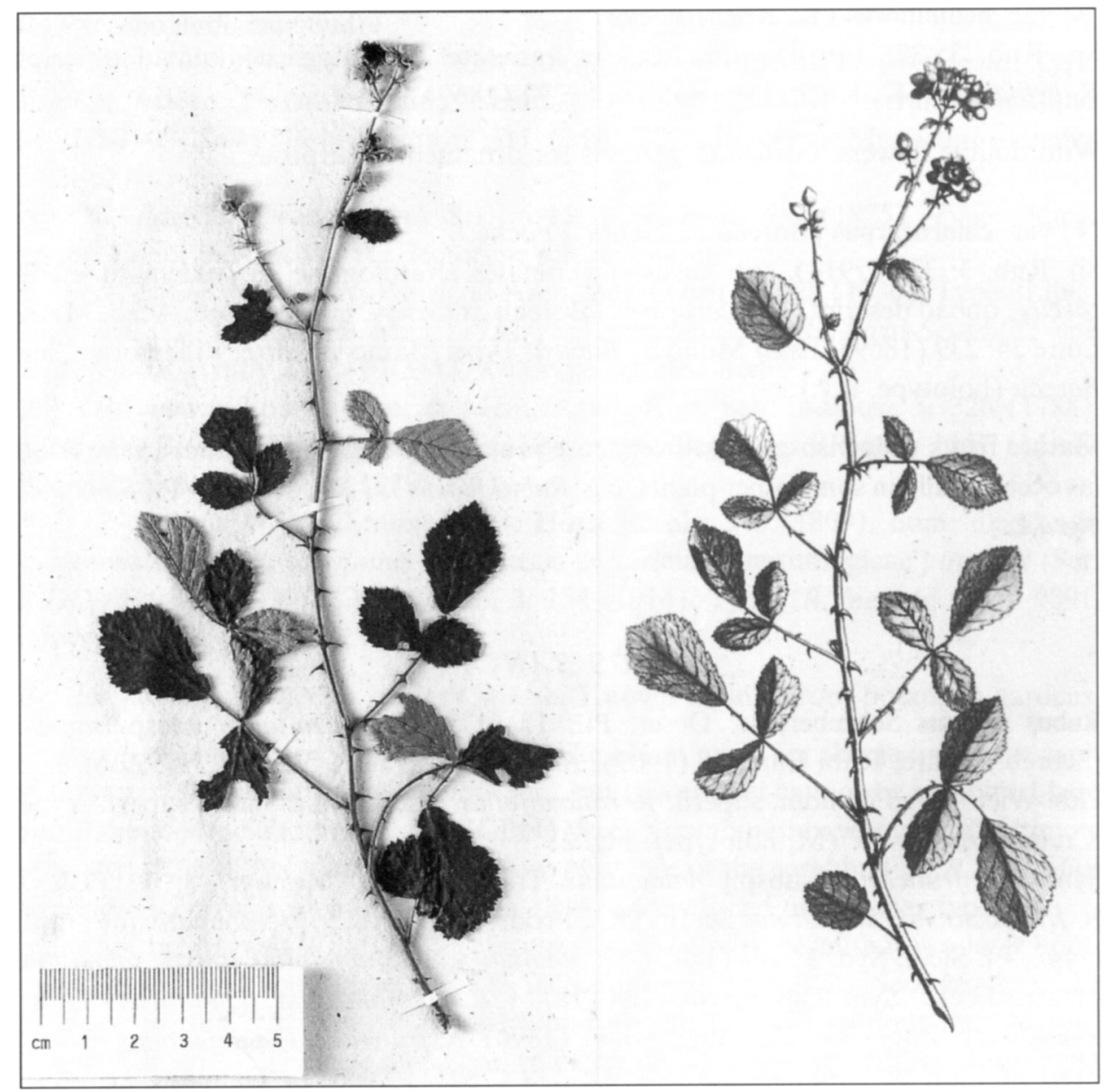

FIG. 2. Rubus sanctus Schreb. Holotype (M, left) which served as the model for plate VIII in Schreber (1766, right).

Rubus sanctus (Fig. 3) differs from R. ulmifolius Schott as follows: Primocane and other axes not pruinose, but felty and with very dense, short patent hairs, prickles often patent and straight. Leaves densely hairy above (mostly $>100$ short simple and often also stellate hairs per $\mathrm{cm}^{2}$ ), tomentose and markedly soft with longer hairs beneath. Terminal leaflet more rounded (the other leaflets also to a certain extent), mostly broadly obovate, abruptly narrowed beyond the tip and distinctly mucronate. often coarsely serrate. Rachis of the panicle shortly villous and tomentose, pedicels also tomentose and shortly villous with patent hairs up to $0.5 \mathrm{~mm}$ long. Anthers always (mostly densely) hairy.

Distribution. Eastern Mediterranean area (replacing $R$. ulmifolius Schott in the eastern part of its distribution area), Syria, Iran, Caucasian countries. Crimea to 


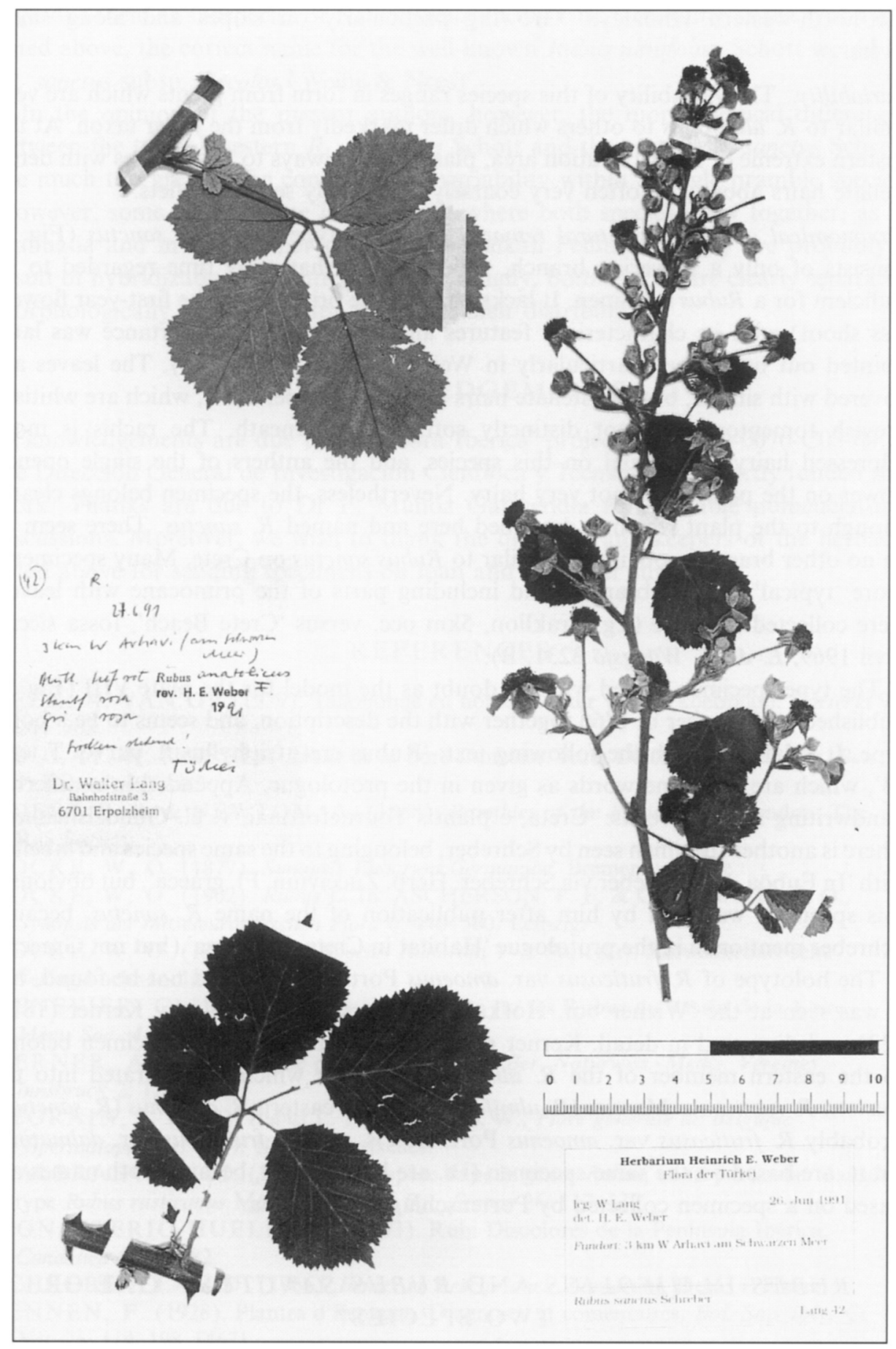

FIG. 3. Rubus sanctus Schreb. Specimen normale (from Turkey, We). 
the north-western Himalaya. Growing particularly on slopes and along small rivers.

Variability. The variability of this species ranges in form from plants which are very similar to $R$. ulmifolius to others which differ markedly from the latter taxon. At the eastern extreme of its distribution area, plants seem always to have leaves with dense stellate hairs above and often very coarsely and deeply serrate leaflets.

Taxonomical and nomenclatural remarks. The holotype of Rubus sanctus (Fig. 2) consists of only a flowering branch, which was at that early time regarded to be sufficient for a Rubus specimen. It lacks parts of the primocane (the first-year flowerless shoot) with its characteristic features and leaves, whose importance was later pointed out by Weihe (particularly in Weihe \& Nees, 1822-1827). The leaves are covered with simple, but not stellate hairs above $\left(>200\right.$ per $\left.\mathrm{cm}^{2}\right)$, which are whitishgreyish tomentose, but not distinctly softly hairy beneath. The rachis is more adpressed hairy than usual on this species, and the anthers of the single opened flower on the panicle are not very hairy. Nevertheless, the specimen belongs clearly enough to the plant which is described here and named $R$ sanctus. There seem to be no other brambles obviously similar to Rubus sanctus on Crete. Many specimens, more 'typical' for this bramble and including parts of the primocane with leaves, were collected at Crete (e.g. 'Iraklion, $5 \mathrm{~km}$ occ. versus 'Crete Beach', fossa sicca', 2 vii 1969, E. \&. G. Wängsjö 3231, B).

The type specimen served without doubt as the model for the plate VIII (Fig. 2) published by Schreber in 1766 together with the description, and seems to be a holotype. It is labelled with the following text: 'Rubus cret. triphyllus fl. parvo. T. car. 43 ', which are the same words as given in the protologue. Appended in a different handwriting are the words: 'Creta, e plantis Tournefortinai, v. cl. Gundelsheimer'. There is another specimen seen by Schreber, belonging to the same species and labelled with 'In Euböa. Herb. Sieber via Schreber. Herb. Zuccivinii. Fl. graeca', but obviously this specimen was seen by him after publication of the name $R$. sanctus, because Schreber mentioned in the protologue 'Habitat in Creta, Palestina' (but not Graeca).

The holotype of $R$. fruticosus var. amoenus Port. ex Vis. could not be found, but it was seen at the 'Wiener bot. Hofkabinet' (Focke, 1877: 184) by Kerner (1872: 132 ) and discussed in detail. Kerner pointed out clearly that this specimen belongs to the eastern member of the $R$. ulmifolius complex which he separated into the western $R$. rusticanus Mercier ( $R$. ulmifolius) and the eastern $R$. amoenus ( $R$. sanctus). Probably $R$. fruticosus var. amoenus Port. ex Vis. and $R$. fruticosus var. dalmatinus Tratt. are based on the same specimen (i.e. are homotypic), because both names are based on a specimen collected by Portenschlag in Dalmatia.

\section{RUBUS ULMIFOLIUS AND RUBUS SANCTUS - ONE OR TWO SPECIES?}

Without doubt the plants treated here and separated as $R$. ulmifolius Schott and $R$. sanctus Schreb. are closely related. Some taxonomists (e.g. Focke, 1902, 1910-14) 
regarded them as subspecies of $R$. ulmifolius. In this case, according to the synonyms listed above, the correct name for the well-known Rubus ulmifolius Schott would be ' $R$. sanctus subsp. discolor (Weihe \& Nees)'.

In the opinion of the present authors, however, the morphological differences between the typical western $R$. ulmifolius Schott and the eastern $R$. sanctus Schreb. are much too great to be considered as variability within a single bramble species. However, some intermediate forms occur where both species grow together, as in Dalmatia and in some other parts of the Balkan Peninsula. They are probably a result of hybridization and introgression. Usually, both species are clearly separated morphologically as well as with respect to their distribution.

\section{ACKNOWLEDGEMENTS}

Acknowledgements are due to the 'Flora Iberica' project no. PB92-0070-C03-00 of the Dirección General de Investigación Científica y Técnica which partly funded this work. Thanks are due to Dr F. Muñoz Garmendia for valuable nomenclatural discussions. Moreover, we wish to thank the directors and keepers of the herbaria listed above for sending specimens on loan and for other support.

\section{REFERENCES}

BEEK, A. VAN DE (1979). Taxonomie en nomenclatuur van de koebraam. Gorteria 9: 204-208.

BOULAY, N. (1898). Les Rubus de la flore française. Rubi Discolores. Bull. Soc. Bot. France 45: 497-582.

EDEES, E. S. \& NEWTON, A. (1988). Brambles of the British Isles. London: The Ray Society.

FOCKE. W. O. (1877). Synopsis Ruborum Germaniae. Bremen.

FOCKE, W. O. (1902). Rubus L. In: ASCHERSON, P. F. \& GRAEBNER, K. O., Sinopsis der mitteleuropäischen Flora 6: 440-560. Leipzig.

FOCKE, W. O. (1910-1914). Species Ruborum 1-3. Stuttgart. Schweizerbart'sche Verlagsbuchhandlung.

GENEVIER. G. (1868). Essai monographique sur les Rubus du bassin de la Loire. Mém. Soc. Acad. Maine Loire 24: 1-346.

KERNER, A. (1872). Novae plantarum species. Ber. Naturwiss.-Mediz. Vereines Innsbruck 2: 124-173.

LEGR A IN, J. (1958). Rubus L. In: ROBYNS, W., Flore générale de Belgique (Spermatophytes) 3(1):10-152. Bruxelles.

MALBRANCHE, M. (1879). De l'espèce dans le genre Rubus, et en particulier dans le type Rubus rusticanus Merc. Bull. Soc. Bot. France 26: 117-132.

MONASTERIO-HUELIN. E. (1993). Rubi Discolores de la Península Ibérica. Candollea 48: 61-82.

SCHREBER, J. C. D. (1766). Icones et Desciptiones Plantarum. Decas i. Halae.

SENNEN, F. (1928). Plantes d'Espagne. Diagnoses et comentaires. Bol. Soc. Ibér. Ci. Nat. 26: 114-198. [467].

SENNEN, F. (1936). Diagnoses des nouveautés parues dans les exsiccata Plantes d'Espagne et du Maroc. Vich. 
SUDRE, H. (1908-1913). Rubi Europae. Paris.

WEBER, H. E. (1986). Rubi Westfalici. Münster: Westf. Mus. Naturkunde.

WEBER, H. E. (1995). Rubus L. In: HEGI, G., Illustrierte Flora von Mitteleuropa

IV/2A. Ed. 3 (ed. H. E. Weber), pp. 284-595. Berlin etc.: Blackwell.

WEIHE, K. E. A. \& NEES VON ESENBECK, C. G. (1822-1827), Rubi

Germanici. Elberfeld.

Received 30 August 1995; accepted with minor revision 26 February 1996 